\author{
KAROLINA NOWOSAD \\ Katedra Biotechnologii, Mikrobiologii i Żywienia Człowieka \\ Wydział Nauk o Żywności i Biotechnologii \\ Uniwersytet Przyrodniczy $w$ Lublinie \\ Skromna 8. 20-704 Lublin \\ e-mail:karolina.nowosad@up.lublin.pl
}

\title{
ROLA DIETY I STYLU ŻYCIA W LECZENIU INSULINOOPORNOŚCI
}

\section{ROLA OTYŁOŚCI W POWSTANIU INSULINOOPORNOSCI}

Częstość występowania otyłości gwałtownie rośnie na całym świecie, głównie $z$ powodu znacznych zmian we współczesnym stylu życia ludzi: nadmiernej konsumpcji kalorii, siedzącego trybu życia i stresu (OGURTSOVA i współaut. 2017). Otyłość jest jednym z największych wyzwań medycznych XXI w. U większości osób $z$ nieprawidłową masą ciała (otyłościa lub nadwaga) rozwija się insulinooporność, bowiem otyłość może być jednym z głównych czynników jej ryzyka (PETERSEN i SHulman 2018). Prawdopodobnie tkanka tłuszczowa indukuje stan zapalny, wywiera hamujacy wpływ na utlenianie kwasów tłuszczowych i glukozy, co zostało powiazane $z$ rozwojem miejscowej i ogólnoustrojowej insulinooporności (STEPPAN i współaut. 2001). Otyłość stwarza znaczne ryzyko rozwoju nie tylko insulinooporności, ale i cukrzycy, tym samym skracając oczekiwaną długość życia, Jednak wiele osób otyłych nie rozwija żadnej $z$ tych chorób. Jedna $z$ hipotez wyjaśniających ten dylemat jest to, że całkowita zawartość tkanki tłuszczowej nie jest przyczyna niekorzystnego stanu zdrowia w przypadku otyłości, a względna proporcja lipidów w różnych składach tłuszczu jest tym, co decyduje o ryzyku metabolicznym (CAPRIO i wspólaut. 2018). Dodatkowo, kolejnymi czynnikami mogacymi wpływać na rozwój insulinooporności sa zaburzenia flory bakteryjnej, a dynamika jej struktury wpływa na występowanie i rozwój różnych chorób endokrynnych i metabolicznych (HE i LI 2020). TREMELLEN i PEARCE (2012) zaproponowali hipotezę zwa- na DOGMA (dysbioza mikrobioty jelitowej), która w następujący sposób wyjaśnia możliwa sekwencje zdarzeń $\mathrm{w}$ patogenezie insulinooporności: zwiększenie przepuszczalności ścian jelita, następnie nieszczelne jelito może powodować wyciek lipopolisacharydu (ang. lipopolysaccharide, LPS) do krażenia ogólnoustrojowego, a wynikająca $z$ tego aktywacja układu odpornościowego może zakłócać funkcjonowanie receptora insuliny, powodując insulinooporność.

Otyłość to złożona choroba wieloczynnikowa. Częstość wystẹpowania nadwagi i otyłości na świecie zwiększyła się od 1980 r. do tego stopnia, że prawie jedna trzecia światowej populacji zmaga się $z$ tym problemem. Występowanie otyłości wzrosło w każdym wieku i o obu płci, niezależnie od położenia geograficznego, pochodzenia etnicznego lub statusu społeczno-ekonomicznego, chociaż częstość jej występowania jest ogólnie większa u osób starszych i u kobiet. Do określenia nadwagi i otyłości stosuje się wskaźnik masy ciała BMI (ang. body mass index). BMI oblicza się na podstawie wzoru (CHOOI i współaut. 2019):

$$
B M I=\text { masa ciała }(\mathrm{kg}): \text { wzrost }(\mathrm{m})^{2}
$$

Zakres BMI dla otyłości I stopnia wynosi od 30 do 34,9 (Tabela 1).

Jednak BMI ma niska czułość i istnieje duża międzyosobnicza zmienność procentu tkanki tłuszczowej dla dowolnej wartości BMI, częściowo przypisywana wiekowi, płci i pochodzeniu etnicznemu (CHOOI i współaut. 2019). Samo BMI nie rozróżnia masy beztłuszczowej i tłuszczowej oraz nie uwzglednia oceny rozkładu masy thuszczowej. Kolejnymi 
Tabela 1. Zakresy BMI (JAROsz i współaut. 2020).

\begin{tabular}{ll}
\hline Stan masy ciała & Zakres BMI \\
\hline Niedowaga & Poniżej 18,9 \\
Norma & $19-24,9$ \\
Nadwaga & $25-29,9$ \\
Otyłość I stopnia & $30-34,9$ \\
Otyłość II stopnia & $35-39,9$ \\
Otyłość III stopnia & Powyżej 40 \\
\hline
\end{tabular}

wskaźnikami otyłości moga być: obwód talii WC (ang. waist circumference), obwód bioder HC (ang. hips circumference), stosunek talii do bioder WHR (ang. waist-hip ratio) i stosunek talii do wzrostu WtHR (ang. waist-to-height ratio), które sa użytecznymi wskaźnikami rozmieszczenia tłuszczu i otyłości brzusznej, ale nie dostarczaja informacji na temat objętości wody i masy mięśniowej lub kostnej. Aby poznać kompozycję ciała wykorzystuje się bardziej zaawansowane metody, takie jak tomografia komputerowa CT (ang. computed tomography), magnetyczny rezonans jadrowy NMR (ang. nuclear magnetic resonance), absorpcjometrię rentgenowską o podwójnej energii DXA (ang. dual energy $\mathrm{x}$ -ray absorptiometry), ultradźwięki US (ang. ultrasounds) czy metody bioimpedancji BIA (ang. bioelectrical impedance analysis). DXA dokładnie szacuje masę kości, tłuszczu i mięśni, ale nie ocenia przedziałów objętości wody. Urządzenia BIA, poprzez zastosowanie prąów elektrycznych przesyłanych przez ciało, szacuja objętość wody oraz masę bezthuszczowa i thuszczowa, podczas gdy urzadzenia US oceniaja zawartość tluszczu w poszczególnych narządach w sposób pótilościowy (BAZZOCCHI i współaut. 2016).

\section{MECHANIZMY POWSTANIA INSULINOOPORNOŚCI}

Insulinooporność jest złożonym stanem patologicznym wynikajacym $z$ nieprawidłowej odpowiedzi na hormon insulinę w komórkach insulinozależnych, takich jak adipocyty (komórki tłuszczowe) i kardiomiocyty (YARIBEYGi i współaut. 2019). Prowadzi to do obniżenia zdolności komórek do wchłaniania i wykorzystywania glukozy, uniwersalnego substratu metabolicznego (SAMUEL i SHULMAN 2016).

Insulina jest hormonem anabolicznym, który wywiera różnorodny wpływ na wiele typów komórek. Niektóre $z$ głównych metabolicznych działań insuliny to: stymulowanie wychwytu glukozy w mięśniach szkieletowych i adipocytach, stymulowanie syntezy glikogenu w mięśniach szkieletowych, hamowanie wytwarzania glukozy w watrobie oraz hamowanie lipolizy $\mathrm{w}$ adipocytach. Po



Ryc. 1. Fizjologiczne działanie insuliny (opracowanie własne).

spożyciu posiłku insulina jest wydzielana $z$ trzustki i indukuje wychwyt krązacej glukozy w tkankach docelowych poprzez wiazanie się ze swoim receptorem, co powoduje uregulowanie poziomu glukozy (Ryc. 1) (ORMAZABAL i współaut. 2018).

Fizjologicznie, na poziomie całego organi$z m u$, na działanie insuliny wpływa wzajemne oddziaływanie innych hormonów. Insulina działa wspólnie $z$ hormonem wzrostu i IGF-1; hormon wzrostu jest wydzielany w odpowiedzi na insulinę, m.in. zapobiegając hipoglikemii wywołanej przez insulinę. Inne hormony o działaniu przeciwstawnym do insuliny to glukagon, glukokortykoidy i katecholaminy. Hormony te napędzaja procesy metaboliczne $\mathrm{w}$ stanie postu. Nadmierne wydzielanie tych hormonów może przyczyniać się do insulinooporności w określonych warunkach, ale nie jest warunkiem podstawowym. Uważa się, że w większości przypadków insulinooporność objawia się na poziomie komórkowym poprzez defekty postreceptorowe $\mathrm{w}$ sygnalizacji insulinowej (WILCOX 2005).

Wyróżnia się trzy mechanizmy prowadzace do powstania insulinooporności: przedreceptorowy, receptorowy i postreceptorowy (Tabela 2).

Co ciekawe, niski poziom krażącej insuliny $i$ insulinooporność odgrywaja istotna rolę fizjologiczna podczas głodu i ciaży. Podczas głodu niski poziom glukozy prowadzi do zmniejszenia wydzielania insuliny, co ułatwia mobilizacje glukozy $\mathrm{z}$ wattroby, kwasów tłuszczowych $i$ glicerolu $z$ adipocytów oraz aminokwasów $z$ tkanki mięśniowej. Te mechanizmy kompensacyjne pomagaja utrzymać poziom glukozy we krwi i jej wykorzystanie 
Tabela 2. Mechanizmy powstawania insulinooporności (GRZESIUK i współaut. 2008).

\begin{tabular}{ll}
\hline Oporność na insulinę & Opis \\
\hline przedreceptorowa & Spowodowana nieprawidłową budową cząsteczek insuliny, występowaniem przeciwciał, \\
& które wiążą cząsteczki insuliny, zwiększona degradacją insuliny, obecnością substancji \\
& o działaniu antagonistycznym do insuliny (Ryc. 2) \\
receptorowa & Spowodowana zmniejszeniem ilości receptorów insuliny lub zmniejszeniem ich powino- \\
& wactwa do insuliny \\
postreceptorowa & Spowodowana zaburzeniami w procesach przyłączania się insuliny do receptora, nie- \\
& prawidłowościami w budowie transporterów glukozy \\
\hline
\end{tabular}



Ryc. 2. Mechanizm przedreceptorowy powstania insulinooporności (opracowanie własne).

przez mózg i krwinki czerwone. Insulinooporność wzrasta w czasie ciąży, zwłaszcza od drugiego do trzeciego trymestru. Zapewnia to odpowiednie zaopatrzenie płodu w substraty metaboliczne i składniki odżywcze dla jego prawidłowego wzrostu i rozwoju (BERG i współaut. 2002). Dodatkowo, insulinooporność bierze udział w patogenezie chorób metabolicznych, takich jak cukrzyca typu 2, i może współwystępować w takich chorobach jak: rak piersi, reumatoidalne zapalenie stawów, zespół policystycznych jajników, niealkoholowa stłuszczeniowa choroba watroby i choroby układu krążenia (ORMAZABAL i współaut. 2018).

\section{METODY LECZENIA INSULINOOPORNOŚCI}

Dzięki postępowi medycznemu powstaje coraz więcej metod leczenia insulinooporności. Pozwalaja one na kontrolę stężenia glukozy we krwi (glikemii), a także moga zatrzymać rozwój tego zaburzenia metabolicznego. Ze względu na to, że ryzyko insulinooporności jest silnie powiązane ze środowiskiem, odżywianiem i stylem życia, skupienie się na znanych czynnikach ryzyka poprzez wczesna modyfikację stylu życia pozostaje najskuteczniejsza strategia zmniejszania chorobowości i śmiertelności. Spożywanie odpowiednio zbilansowanych posiłków, w połączeniu $z$ aktywnością fizyczna wspomaga leczenie insulinooporności. Ponadto powstaja nowe metody leczenia, np. genetyczne przeprogramowanie ludzkich komórek oraz wytworzenie komórek produkujacych insulinę $z$ komórek macierzystych (ZDROJEWICZ i współaut. 2014).

\section{DIETA}

Podczas głodu stężenie insuliny utrzymuje się na niskim poziomie, co ułatwia mobilizację kwasów tłuszczowych i glicerolu $z$ tkanki tłuszczowej oraz aminokwasów $z$ mięśni. Przewlekłe nadmierne zużycie energii sprzyja hiperinsulinemii i oporności na insulinę poprzez stymulację wydzielania insuliny, syntezę trójglicerydów i akumulację tłuszczu (GARG i współaut. 2011).

Skład kwasów tłuszczowych w diecie odgrywa dużą rolę w długoterminowym rozwoju insulinooporności poprzez wpływ na skład lipidów błonowych. Wielonienasycone kwasy tłuszczowe o długich łańcuchach wpływają na utrzymanie płynności błony komórkowej i sygnalizacji komórkowej, wpływają również na ekspresję genów. Bardzo ważny jest także odpowiedni stosunek kwasów omega 3 do omega 6 , który powinien wynosić między $1: 2$ a $1: 5$ (BuOite Stella i współaut. 2018). Spożycie białka stymuluje wydzielanie insuliny, sprzyjajacc anabolizmowi; prawdopodobnie pośredniczy $w$ ten sposób w jego wpływie na uczucie sytości. Stymuluje również wydzielanie glukagonu $z$ komórek a trzustki i promuje glukoneogeneze. Jednak długoterminowe badania wskazuja, że odpowiednie spożycie białka obniża ryzyko zachorowania na cukrzycę typu 2 (GOŁĄBEK i REGULSKA- 
-ILOW 2019). Mikroelementy o potencjalnym znaczeniu to cynk i chrom. Cynk odgrywa ważna rolę w biosyntezie i wydzielaniu insuliny. Niedobór chromu wiąże się $z$ nietolerancją glukozy i insulinoopornościa (BJøRKLUND i współaut. 2020).

\section{NISKI INDEKS GLIKEMICZNY}

Najważniejszym czynnikiem w leczeniu insulinooporności jest wprowadzenie diety o niskim indeksie glikemicznym. Koncepcja indeksu glikemicznego (IG) opiera się na różnicy w odpowiedzi glukozy we krwi po spożyciu tej samej ilości węglowodanów $z$ różnych pokarmów. Indeks glikemiczny definiowany jest jako procentowy wzrost stężenia glukozy we krwi po spożyciu produktu zawierającego $50 \mathrm{~g}$ węglowodanów przyswajalnych, w odniesieniu do wzrostu poziomu glukozy we krwi po spożyciu 50 g glukozy (ARVIDSSON-LENNER i współaut. 2004). Wartość indeksu glikemicznego oblicza się wg wzoru:

$I G(\%)=\frac{\text { powierzchnia pod krzywą }(\text { AUC }) \text { dla badanej żywności }}{\text { powierzchnia pod krzywą (AUC) dla próbki referencyjej j }} \times 100$

Aktualne wytyczne dietetyczne zalecaja spożywanie węglowodanów na poziomie 4565\% wszystkich kalorii, a ich źródłem powinny być głównie węglowodany złożone lub skrobia. Właściwości odżywcze węglowodanów w żywności opierają się na dwóch efektach fizjologicznych: dostępności do trawienia i/ lub wchłaniania w przewodzie pokarmowym, czyli zdolności do podwyższania poziomu glukozy we krwi. Taka klasyfikacja potencjału węglowodanów do podwyższania poziomu glukozy we krwi określana jest jako IG żywności. IG został wprowadzony przez Jenkinsa i współpracowników na początku lat 80 . Ubiegłego wieku (patrz NAYAK i współaut. 2014). Pojęcie indeksu glikemicznego zostało pierwotnie wprowadzone w celu klasyfikowania różnych źródeł żywności bogatej w węglowodany (CHOs, ang. carbohydrates), zwykle o zawartości energii $>80 \%$ z CHOs, pod kątem ich wpływu na glikemię poposiłkowa. Przyjęto, że ma dotyczyć żywności, która przede wszystkim dostarcza węglowodanów przyswajalnych, powodując hiperglikemię. Żywność o niskim indeksie glikemicznym (Tabela 3) została sklasyfikowana jako wolno trawiona i wchłaniana, a żywność o wysokim indeksie glikemicznym jako szybko trawiona i wchłaniana, co skutkuje różnymi reakcjami glikemicznymi (CLAR i współaut. 2017). Wybór pokarmów o niskim indeksie glikemicznym umożliwia skuteczna kontrolę poposiłkowych wahań stężenia insuliny i glukozy. W przeciwieństwie do pokarmów o wysokim IG, produkty o niskim IG indukuja jedynie umiarkowane lub niskie podwyższenie poziomu glukozy po spożyciu, co z kolei wywołuje niewielkie wydzielanie insuliny. Duże wzrosty glikemii obserwowane po spożyciu pokarmów o wysokim indeksie glikemicznym często skutkują późniejszym spadkiem wartości glikemii poniżej wartości wyjściowych (GIUBERTI i GALLO 2018).

Indeks glikemiczny został oznaczony dla większości produktów spożywczych. Indeks ten dla niektórych grup produktów węlowodanowych przedstawiono w Tabeli 4. Rośliny stracczkowe, makarony pełnoziarniste, niektóre ryże, chleb na zakwasie i produkty typu kasza bulgur charakteryzuja się niskim IG. Większość produktów ziemniaczanych, chleb i płatki śniadaniowe maja ten indeks wysoki, często wyższy niż w przypadku sacharozy (GiUBERTI i GallO 2018).

Skrobia jest najpowszechniejszym węglowodanem magazynowym w roślinach, a także największym źródłem węglowodanów w żywności dla ludzi. Skrobia składa się $z$ dwóch rodzajów cząsteczek: amylozy (liniowy polimer jednostek a-D-glukozy połączonych wiązaniami a-1,4 glikozydowymi) i amylopektyny (rozgałęziony polimer jednostek a-D-glukozy połaczonych wiązaniami a-1,4 i a-1,6 wiązań glikozydowych). Skrobię i zawierajace ja produkty spożywcze można klasyfikować według ich strawności, która charakteryzuje szybkość i czas trwania odpowiedzi glikemicznej. Przewidywanie i kontrolowanie wchłaniania

Tabela 3. Wartości indeksu glikemicznego.

\begin{tabular}{ll}
\hline Indeks glikemiczny & Wartość \\
\hline Niski & $<50$ \\
Średni & $51-70$ \\
Wysoki & $>70$ \\
\hline
\end{tabular}

Tabela 4. Wybrane produkty spożywcze o niskim indeksie glikemicznym.

\begin{tabular}{ll}
\hline Produkt spożywczy & $\begin{array}{l}\text { Wartość indeksu gli- } \\
\text { kemicznego }\end{array}$ \\
\hline Produkty zbożowe & \\
\hline Kasza gryczana & 40 \\
Płatki owsiane (nieugotowane) & 40 \\
Chleb żytni & 50 \\
\hline Owoce & \\
\hline Truskawki & 25 \\
Banan świeży & 45 \\
Kiwi & 50 \\
\hline Warzywa & 15 \\
\hline Pomidor & 15 \\
Papryka czerwona & 26 \\
Soczewica czerwona gotowana & \\
\hline Nabiał & 0 \\
\hline Jaja & 0 \\
Ser żółty & 21 \\
Mleko spożywcze 2\% & \\
\hline
\end{tabular}


glukozy w wyniku spożywania produktów bogatych w skrobie jest bardzo interesujace w kontekście ogólnoświatowych problemów zdrowotnych (BELLO-PEREz i współaut. 2020). Niższym IG charakteryzują się produkty, które posiadaja większy stosunek amylozy do amylopektyny. Zależy to przede wszystkim od stopnia żelowania, który jest zależny od ilości amylozy. Niższa zawartość amylozy w produkcie zwiazana jest $z$ wyższym stopień żelowania, przez co skrobia jest łatwiej rozkładana przez a-amylazę. W rezultacie do krwiobiegu wchłaniane sa większe ilości glukozy, które powoduja wzrost glikemii. Osoby $z$ insulinoopornościa powinny ograniczać produkty zawierające skrobię kukurydziana, której indeks glikemiczny wynosi 100. Jest ona całkowicie pozbawiona amylozy, przez co powoduje wysoki wzrost stężenia glukozy we krwi i nadmierne wydzielanie insuliny (MAGALlanES-CRUZ i współaut. 2017).

$\mathrm{Na}$ indeks glikemiczny produktu wpływa również zawartość skrobi opornej. Skrobię dzielimy na skrobię szybko trawiona (RDS), skrobię wolnotrawiona (SDS) oraz skrobię, która jest oporna na trawienie (skrobia oporna RS). Zawartość skrobi opornej wylicza się na podstawie wzoru, gdzie TS oznacza ogólna zawartość skrobi w produkcie (FUENTES-ZARAGOZA i współaut. 2010):

$$
R S=T S-(R D S+S D S)
$$

Skrobia oporna (RS) to frakcja skrobi, która jest odporna na trawienie w jelicie cienkim, docierajac do jelita grubego $\mathrm{w}$ stanie nienaruszonym. RS jest następnie fermentowany przez drobnoustroje w jelicie grubym, wytwarzajac krótkołańcuchowe kwasy tłuszczowe (SCFA). RS przypisano szereg korzyści zdrowotnych, m.in. wpływa na poprawę stanu jelit, pomaga kontrolować glikemię i stężenie lipidów, zwiększa uczucie sytości i pomaga kontrolować masę ciała. Skrobia oporna jest zaliczana do składników nierozpuszczalnego błonnika pokarmowego. Spożycie błonnika wiąże się ze zmniejszeniem ryzyka rozwoju cukrzycy typu 2, chorób układu krążenia (CVD) i raka jelita grubego (DEMARTINO i COCKBURN 2020).

Techniki kulinarne również mają wpływ na IG żywności, np. ziemniaków. Ziemniaki sa jednym $z$ najpopularniejszych produktów weglowodanowych w krajach uprzemysłowionych i niektórych krajach rozwijajacych się. Jednak sprzeczne argumenty i nieporozumienia dotyczące ziemniaków jako żywności o wysokim indeksie glikemicznym bezpośrednio wpływaja na spożycie ziemniaków w ostatnich latach. Surowe świeże ziemniaki zawieraja mniej strawnej skrobi $(10 \%)$, podczas gdy gotowane i puree sa bardziej strawne (odpowiednio 78\% i 70\% strawnej skro- bi). Smażone ziemniaki, np. frytki, zawieraja około 7\% opornej skrobi. Zmiany ilościowe różnych rodzajów skrobi w wybranych warunkach przetwarzania zależą od dostępności wody. Pieczenie i smażenie w głębokim tłuszczu ograniczają dostępność wody, dzięki czemu ziemniaki smażone i pieczone wykazują mniejszą zawartość skrobi ogółem w porównaniu $z$ ziemniakami surowymi i gotowanymi. Jednocześnie ilość skrobi opornej zmniejsza się również podczas smażenia ziemniaków i bezpośrednio po usmażeniu, a następnie wzrasta podczas chłodzenia $Z$ retrogradacja. Dodatkowo, wstępne gotowanie i podgrzewanie ziemniaków przed spożyciem powoduje zmniejszenie odpowiedzi glikemicznej $\mathrm{w}$ porównaniu $z$ ziemniakami spożywanymi natychmiast po ugotowaniu. Powtarzające się ogrzewanie i chłodzenie powoduja powstanie większych ilości skrobi opornej, co wpływa na odpowiedź glikemiczna poprzez spowolnienie trawienia i wchłaniania glukozy do krwi (NAYAK i współaut. 2014).

$\mathrm{Na}$ poposiłkowa odpowiedź glikemiczna wpływa nie tylko indeks glikemiczny pokarmu, ale także ilość spożytych węglowodanów. Ładunek glikemiczny (ŁG) jest wartościa odnosząca się do porcji produktu spożywczego zawierajacego węglowodany (Tabela 5). Ładunek glikemiczny określa wpływ spożycia danego produktu na zmiany poziomu glukozy we krwi. Jest to dokładniejszy parametr niż indeks glikemiczny, ze względu na to, że uwzględnia nie tylko rodzaj węglowodanów i szybkość ich wchłaniania, ale także ilość węglowodanów zawarta w porcji produktu (VEGA-LóPEZ i współaut. 2018). Ładunek glikemiczny wylicza się ze wzoru:

$€ G=\frac{\text { ilość węglowodanów przyswajalnych } w \text { produkcie }(g) \times \text { indeks glikemiczny }}{100}$ 100

\section{ZMIANA STYLU ŻYCIA}

Wzrost występowania otyłości zarówno u mężczyzn, jak i kobiet stanowi poważny problem zdrowia publicznego i wzmacnia potrzebę opracowania skutecznych strategii leczenia. Najważniejszym czynnikiem w przypadku konieczności utraty masy ciała jest wprowadzenie diety odchudzajacej. Dodatkowo, utrata masy ciała spowodowana dieta redukcyjna i wysiłkiem fizycznym wiąże się z większą redukcją całkowitej tkanki tłuszczowej, zachowaniem beztłuszczowej masy tkanki i wzrostem wydolności krążeniowo-oddechowej. Ćwiczenia fizyczne zwiazane sa ze znacznym wzrostem lipolizy w brzusznej podskórnej tkance tłuszczowej, co sugeruje, że utrata masy ciała wywołana wysiłkiem wiazałaby się $z$ preferencyjnym zmniejszeniem otyłości brzusznej, a to $z$ kolei prowa- 
Tabela 5. Wartości ładunku glikemicznego.

\begin{tabular}{lc}
\hline Wartość ładunku glikemicznego \\
\hline Niski & Poniżej 10 \\
Średni & $10-20$ \\
Wysoki & Powyżej 20 \\
\hline
\end{tabular}

dziłoby do zmniejsza insulinooporności (HENRIKSEN 2002).

Insulinooporność mięśni szkieletowych jest cechą charakterystyczną osób otyłych oraz pacjentów $z$ cukrzyca typu 2 i wpływa na metabolizm insuliny, transport glukozy, aktywność heksokinazy i ekspresję genów, synteze glikogenu i utlenianie glukozy. Zidentyfikowano kilka potencjalnych mediatorów insulinooporności, w tym np. błędy w przekazywaniu sygnału insuliny $\mathrm{w}$ mięśniach szkieletowych, błędy w ekspresji genów i regulacji enzymów. Istnieja obecnie dowody na to, że brak aktywności fizycznej jest bezpośrednio powiązany $z$ tymi (i innymi, jak dotąd niezidentyfikowanymi) czynnikami i może przyczyniać się do kaskady zdarzeń prowadzących do powstania oporności na insulinę. Brak aktywności fizycznej wywołuje szereg zmian zarówno w wydolności funkcjonalnej całego ciała, jak i metabolizmie mięśni, przy czym większość metabolicznych skutków braku aktywności fizycznej na insulinooporność ma szybki początek i stosunkowo krótki czas trwania. Na przykład insulinooporność szybko wzrasta już po kilku dniach braku aktywności, głównie $z$ powodu zmniejszenia wrażliwości na insulinę, a nie zmniejszenia odpowiedzi na insulinę. Zmniejszone zdolności glikolityczne i oksydacyjne (spowodowane spadkiem aktywności enzymów oksydacyjnych i glikolitycznych) mięśni szkieletowych przyczyniaja się do stanów insulinooporności zarówno u otyłych osób bez cukrzycy, jak i u pacjentów $z$ cukrzyca typu 2 (HAwLEY 2004).

Spożywanie alkoholu hamuje sygnalizacje insuliny i insulinopodobnego czynnika wzrostu w wątrobie i mózgu. Te zmiany spowodowane przez alkohol powoduja ciężka insulinooporność wątroby i ośrodkowego układu nerwowego, ponieważ komórki nie przekazują odpowiednio sygnałów, które sa potrzebne do syntezy DNA i regeneracji wattroby oraz wykorzystania glukozy przez komórki. Przewlekłe spożywanie alkoholu powoduje stłuszczeniowe zapalenie watroby, które sprzyja również insulinooporności wątroby, stresowi oksydacyjnemu i urazom, $z$ towarzyszacym zwiększonym wytwarzaniem "toksycznych lipidów", takich jak ceramidy, które zwiększaja insulinooporność. Cytotoksyczne ceramidy transportowane $z$ wątroby do krwi moga przedostawać się do mózgu ze względu na ich rozpuszczalność w tłuszczach, a tym samym wywierać działanie neurodegeneracyjne poprzez oś wątroba-mózg. Prawdopodobnie neurotoksyczne i neurodegeneracyjne działanie ceramidów pochodzenia wątrobowego aktywuje cytokiny prozapalne i powoduje insulinooporność w mózgu, co prowadzi do zaburzeń funkcji poznawczych i motorycznych (DE LA MonTe i współaut. 2012).

Palenie jest jedna $z$ najczęstszych przyczyn zachorowalności i śmiertelności na całym świecie oraz jest niezależnym czynnikiem ryzyka rozwoju chorób układu sercowo-naczyniowego i cukrzycy typu 2. Według raportu Amerykańskiego Centrum Chorób (NCCDPHP 2014) palenie zwiększa ryzyko cukrzycy i insulinooporności o $30-40 \%$ dla aktywnych palaczy $\mathrm{w}$ porównaniu $\mathrm{z}$ osobami niepalącymi, co sugeruje, że zaprzestanie palenia powinno być podkreślane jako kluczowa strategia zdrowia publicznego, mająca na celu zwalczanie globalnej epidemii cukrzycy i insulinooporności. Niestety, związek między paleniem, biernym paleniem i insulinoopornościa jest nieznany. Papierosy i inne produkty do palenia zawieraja mieszankę dodatków chemicznych, które moga wpływać na metabolizm. Nikotyna jest jedną $z$ głównych substancji bioaktywnych w papierosach $i$ jest jednym $z$ najczęściej pobieranych dodatków. Nikotyna to naturalnie wytwarzany przez tytoń alkaloid, który wiąże się z receptorem znajdującym się $\mathrm{w}$ narządach neuronalnych i nieneuronalnych lub trzewnych. Receptory te uczestnicza w sygnalizacji w obrębie ośrodkowego i obwodowego układu nerwowego oraz w wielu tkankach, w tym w wyspach trzustkowych, tkance tłuszczowej, makrofagach, wattrobie i mięśniach szkieletowych. Wykazano również, że nikotyna działa bezpośrednio na homeostazę glukozy, co sugeruje jej istotna rolę $\mathrm{w}$ rozwoju insulinooporności. Upośledzenie wrażliwości na insulinę jest proporcjonalne do użycia tytoniu (HARRIS i współaut. 2016). Palenie wiąże się z dysfunkcja śródbłonka i zaburzeniami lipidowymi, podobnymi do występujacych w zespole insulinooporności. Dodatkowo, przyrost masy ciała, często występujacy po rzuceniu palenia, może przyczyniać się do powstania insulinooporności. Palenie papierosów powoduje również wzrost poziomu metali ciężkich $\mathrm{w}$ surowicy krwi, takich jak: ołów, arsen i kadm. Jednak wplyw tych substancji na homeostaze glukozy nie jest do końca wyjaśniony (MADDATU i współaut. 2017).

Przewlekły stres i nadmierne wydzielanie hormonów stresu przyczyniaja się do zwiększenia ryzyka zachorowania na zespół metaboliczny, zaburzenia autoimmunologiczne, cukrzycę typu 2 i zespół policystycznych jaj- 
ników (PCOS). Stres powoduje objawy psychologiczne i somatyczne, zwiększenie masy tłuszczowej, osteosarkopenię/słabość, odwodnienie komórkowe i przewlekłe zapalenie ogólnoustrojowe (STEFANAKI i współaut. 2018). Stres może wpływać na zdrowie poprzez złożone interakcje między reakcjami neuroendokrynnymi a homeostaza energetyczną. Jednym $z$ głównych układów neuroendokrynnych reagujacych na stres psychologiczny jest oś podwzgórze-przysadka-nadnercza (HPA), której ostatecznym efektorem hormonalnym jest wydzielanie kortyzolu. Jako wskaźnik aktywności HPA, kortyzol jest ważnym sygnałem hormonalnym odpowiedzi na przewlekły stres. Przypuszcza się, że podwyższony poziom kortyzolu indukuje akumulację trzewnej tkanki tłuszczowej i stymuluje szlaki glukoneogenezy i lipolizy, co może skutkować powstaniem oporności na insulinę (MCEWEN 2008).

\section{PODSUMOWANIE}

Insulinooporność jest zaburzeniem metabolicznym objawiającym się zmniejszona wrażliwością komórek na insulinę. Głównymi czynnikami zwiększającymi ryzyko rozwoju insulinooporności są: nieprawidłowa dieta $z$ duża podażą kalorii, brak aktywności fizycznej, stres i używki takie jak alkohol, papierosy. W leczeniu tego zaburzenia bardzo ważna jest zmiana stylu życia i diety. Istniejacce dane sugeruja, że dieta o niskim indeksie glikemicznym, bogata w kwasy omega 3, produkty pełnoziarniste oraz warzywa poprawia profil lipidowy i może mieć korzystny wpływ na insulinooporność, zwiększając wrażliwość komórek na insulinę.

\section{Streszczenie}

Insulinooporność to stan zmniejszonej odpowiedzi biologicznej tkanek na insulinę. Obserwowany obecnie wzrost występowania insulinooporności spowodowany jest głównie nieprawidłowym stylem życia, niezdrowa dieta $\mathrm{z}$ duża podażą kalorii i stresem. Niekontrolowana insulinooporność może prowadzić do zwiększenia ryzyka zachorowania na cukrzycę typu 2, choroby układu krażenia, chorobę Alzheimera i depresji. Jednym $z$ potencjalnie modyfikowalnych czynników ryzyka insulinooporności jest dieta. Wprowadzenie diety o niskim indeksie glikemicznym pomaga $\mathrm{w}$ utrzymaniu prawidłowego stężenia glukozy i insuliny we krwi. Dodatkowo, wprowadzenie aktywności fizycznej, redukcja stresu i eliminacja używek wpływaja korzystnie na kontrolę glikemii. Celem niniejszej pracy jest omówienie roli diety i stylu życia w leczeniu insulinooporności oraz przedstawienie mechanizmów powstawania i wpływ otyłości na rozwój insulinooporności.

\section{LITERATURA}

ARVIDSSON-LENNER R., ASP N. G., AXELSEN M., BRYNGELSSON S., HAAPA E., JÄRVI A., VESSBY
B., 2004. Glycaemic index. Scand. J. Nutr. 48, 84-94.

Bazzocchi A., Filonzi G., Ponti F., Albisinni U., Guglielmi G., BATTISTA G., 2016. Ultrasound: Which role in body composition? Eur. J. Radiol. 85, 1469-1480.

Bello-Perez L. A., Flores-Silva P. C., AGAMA-ACEVEDO E., TOVAR J., 2020. Starch digestibility: past, present, and future. J. Sci. Food Agric. 100, 5009-5016.

Berg J., Tymoczko J., STRYer L., 2002. Food intake and starvation induce metabolic changes. [W:] Biochemistry 5th edition. FREEMAN W. H. (red.). New York, 749-750.

BJøRKLUND G., DADAR M., PIVINA L., DOSA M. D., SEMENOVA Y., AASETH, J., 2020. The role of zinc and copper in insulin resistance and diabetes mellitus. Curr. Med. Chem. 27, 66436657.

Buoite Stella A., Gortan Cappellari G., BarazZONI R., ZANETTI M., 2018. Update on the impact of omega 3 fatty acids on inflammation, insulin resistance and sarcopenia: A review. Int. J. Mol. Sci. 19, doi: 10.3390/ ijms 19010218.

Caprio S., Pierpont B., Kursawe R., 2018. The "adipose tissue expandability" hypothesis: a potential mechanism for insulin resistance in obese youth. Horm. Mol. Biol. Clin. Investig. 33, doi: 10.1515/hmbci-2018-0005.

Chooi Y. C., Ding C., Magkos F., 2019. The epidemiology of obesity. Metabolism 92, 6-10.

Clar C., Al-Khudairy L., LOVEman E., Kelly S. A., HARTLEY L., FlOWERS N., REES K. 2017. Low glycaemic index diets for the prevention of cardiovascular disease. Cochrane Database Syst. Rev. 7, doi: 10.1002/14651858. CD004467.pub3.

DE LA MONTE S., DERDAK Z., WANDS J. R., 2012. Alcohol, insulin resistance and the liver-brain axis. J. Gastroenterol. Hepatol. 27, 33-41.

DEMARTINO P., COCKBURN D. W., 2020. Resistant starch: impact on the gut microbiome and health. Curr. Opin. Biotechnol. 61, 66-71.

FUENTES-ZARAGOZA E., RIQUELME-NAVARRETE M. J., SÁnchez-Zapata E., PÉreZ-Álvarez J. A., 2010. Resistant starch as functional ingredient: A review. Food Res. Int. 43, 931-942.

Garg R., Williams G. H., HURWITZ S., BROWN N. J., HOPKINS P. N., ADLER G. K., 2011. Low-salt diet increases insulin resistance in healthy subjects. Metabolism 60(7), 965-968.

GiUBERTI G., GAllo A., 2018. Reducing the glycaemic index and increasing the slowly digestible starch content in gluten-free cereal-based foods: A review. Int. J. Food Sci. 53, 50-60.

GoŁABEK K. D., REgulska-Ilow B., 2019. Dietary support in insulin resistance: An overview of current scientific reports. Adv. Clin. Exp. Med. 28, 1577-1585.

GRZESIUK W., SZYDLARSKA D., JÓŹWIK K., 2008. Insulinooporność $w$ endokrynopatiach. Endocrinol. Obes. Metab. Disord. 4, 38-44.

HARRIS K. K., ZOPEY M., FRIEDMAN T. C., 2016. Metabolic effects of smoking cessation. Nat. Rev. Endocrinol. 12, 299-308.

HAWLEY J. A., 2004. Exercise as a therapeutic intervention for the prevention and treatment of insulin resistance. Diabetes Metab. Res. Rev. 20, 383-393.

HE F. F., LI Y. M., 2020. Role of gut microbiota in the development of insulin resistance and the mechanism underlying polycystic ovary syndrome: A review. J. Ovarian Res. 13, 1-13. 
HENRIKSEN E. J., 2002. Invited review: Effects of acute exercise and exercise training on insulin resistance. J. Appl. Physiol. 93, 788-796.

JAROSZ M., RYCHLIK E., STOŚ K., CHARZEWSKA J. 2020. Normy żywienia dla populacji Polski $i$ ich zastosowanie. Narodowy Instytut Zdrowia Publicznego - $\mathrm{PZH}$, Warszawa.

MADDATU J., ANDERSON-BAUCUM E., Evans-Molina C. 2017. Smoking and the risk of type 2 diabetes. Transl. Res. 184, 101-107.

Magallanes-CRUZ P. A., Flores-Silva P. C., BelLO-PEREZ L. A., 2017. Starch structure influences its digestibility: a review. J. Food Sci. 82, 2016-2023.

MCEWEN B. S., 2008. Central effects of stress hormones in health and disease: Understanding the protective and damaging effects of stress and stress mediators. Eur. J. Pharmacol. 583, 174-185.

NAYAK B., BERRIOS J. D. J., TANG J., 2014. Impact of food processing on the glycemic index (GI) of potato products. Food Res. Int. 56, 3546.

OGURTSOVA K., DA ROCHA FERNANDES J. D., HuANG Y., LinNENKAMP U.,GUARIGUATA L., CHO N., MAKAROFF L. E., 2017. IDF diabetes atlas: Global estimates for the prevalence of diabetes for 2015 and 2040. Diabetes Res. Clin. Pract. 128, 40-50.

Ormazabal V., NaIR S., Elfeky O., Aguayo C., SAlOMON C., ZuÑIGA F. A., 2018. Association between insulin resistance and the development of cardiovascular disease. Cardiovasc. Diabetol. 17, 1-14.

Petersen M. C., Shulman G. I., 2018. Mechanisms of insulin action and insulin resistance. Physiol. Rev. 98, 2133-2223.
SAMUEL V. T., SHUlman G. I. 2016. The pathogenesis of insulin resistance: Integrating signaling pathways and substrate flux. J. Clin. Investig. 126, 12-22.

Stefanaki C., Pervanidou P., Boschiero D., Chrousos G. P., 2018. Chronic stress and body composition disorders: implications for health and disease. Hormones 17, 33-43.

Steppan C. M., Bailey S. T., Bhat S., Brown E. J., BANERJEe R. R., Wright C. M., PATEL H. R., AHIMA R. S., LAZAR M. A., 2001. The hor mone resistin links obesity to diabetes. Nature 409, 307-312.

NCCDPHP (National Center for Chronic Disease Prevention and Health Promotion (US) Office on Smoking and Health), 2014 .The Health Consequences of Smoking-50 Years of Progress: A Report of the Surgeon General. Atlanta (GA).

Tremellen K., PeArCe K., 2012. Dysbiosis of Gut Microbiota (DOGMA) - a novel theory for the development of Polycystic Ovarian Syndrome. Med. Hypotheses 79, 104-112.

Vega-López S., VenN B. J., SlaVin J. L., 2018. Relevance of the glycemic index and glycemic load for body weight, diabetes, and cardiovascular disease. Nutrients 10, doi: 10.3390/ nu10101361.

WilcoX G., 2005. Insulin and insulin resistance. Clin. Biochem. Rev. 26, 19-39.

YARIBEYGi H., FARROKHI F. R., BUTLER A. E., SAHEBKAR A., 2019. Insulin resistance: Review of the underlying molecular mechanisms. J. Cell. Physiol. 234, 8152-8161.

ZdRoJeWicZ Z., BugaJ B., CABAEA K., PyPNo D., WARACKI M., 2014. Nowoczesne kierunki leczenia cukrzycy. Diabetol. Klin. 3, 198-205. 
Kosmos Vol. 70, 4, 731-739, 2021

\section{KAROLINA NOWOSAD}

Department of Analysis and Evaluation of Food Quality, Faculty of Food Sciences and Biotechnology, University of Life Sciences in Lublin, 8 Skromna Str., 20-704 Lublin,E-mail: karo.nowosad@gmail.com

\section{THE ROLE OF DIET AND LIFESTYLE IN THE TREATMENT OF INSULIN RESISTANCE}

\section{Summary}

Insulin resistance is a state of diminished biological tissue response to insulin. The increase in insulin resistance observed nowadays is mainly caused by an incorrect lifestyle, unhealthy diet with a large supply of calories and stress. Untreated insulin resistance can lead to an increased risk of developing type 2 diabetes, cardiovascular disease, Alzheimer's disease, and depression. One of the potentially modifiable risk factors for insulin resistance is diet. Introducing a diet with a low glycemic index helps to maintain normal blood glucose and insulin levels. In addition, the introduction of physical activity, stress reduction and elimination of stimulants have a positive effect on glycemic control. The purpose of this review is to discuss the role of diet and lifestyle in treating insulin resistance. The review presents the mechanisms of development and the impact of obesity on insulin resistance.

Key words: insulin resistance, low glycemic index, resistant starch 